\title{
Use of fetal eggs in research to be debated
}

London. Scientists working in embryo research and infertility treatment could soon use eggs taken from aborted fetuses. In response to this development, the UK Human Fertilization and Embryology Authority (HFEA) last week said that it would ask the public to suggest how it should regulate the use of eggs from aborted fetuses in embryo research and infertility treatment.

Animal research suggests that the use of such eggs will soon be feasible for both applications. Similarly, doctors may soon be able to transplant fetal ovaries, potentially a radical new way to treat infertility. But those carrying out research into both techniques recognize that each raises new ethical issues.

Robert Edwards - the British pioneer of in vitro fertilization (IVF) - says he raised the idea of using fetal eggs for research in a paper published in 1975 . Fertility laboratories have shown increasing interest in recent years because of shortages of eggs provided by donors for research.

"Fetal eggs have the potential for many medical and scientific uses," says Colin Campbell, professor of law at the University of Birmingham and chairman of the HFEA. "The authority's formal interest lies in their potential for use in embryo research and infertility treatment; however, profound ethical questions first need to be addressed."

Doing research with fetal eggs raises even more complex ethical issues than with other fetal tissue (in particular as a potential treatment for Parkinson's disease). A child, for example, could know its grandmother although its biological mother had never been born. Would the man who helped to create the fetus have any rights over his germ-line tissue?

The committee set up to establish guidelines for the use of fetal tissue in research under the physicist and theologian John Polkinghorne, who is president of Queens' College, Cambridge, did not consider the question of eggs. Some of its conclusions would almost certainly be inappropriate: for example that mothers should not be given details of how tissue from her fetus is subsequently used.

HFEA officials say they will set out the scientific prospects in a consultation document later this year; this will cover both fetal eggs and those taken from dead women. HFEA will use the responses in reaching its conclusions on how to regulate research and eventual treatment.

Roger Gosden, a senior lecturer in physiology at the University of Edinburgh who is pioneering research into the possibilities of ovarian transplantation, welcomes the HFEA initiative. Given the demand for infertility treatment, he says, the HFEA needed to clarify what sort of research and treatment society considers acceptable: "We need an authoritative consensus view to clear the way, and to provide an ethical basis on which we can move forward."

Edwards also says that he welcomes the debate about using fetal eggs for research. He warns that scientists who proceed faster than public opinion is prepared to accept run the risk of creating a backlash. "Personally I am against working with fertilized eggs originating from fetal ovaries just yet," says Edwards. "I would like to move more slowly, for example using such eggs to study how

follicles develop, and that sort of thing."

In January, the HFEA consulted the public about sex selection techniques. Twothirds of the respondents said these should be permitted for medical but not for purely social reasons. They thought it acceptable, for example, if a woman risked bearing a child with a life-threatening disease. HFEA has now incorporated this conclusion into its code of practice, which all clinics registered to perform in vitro fertilization must follow.

David Dickson

\section{Australia reconsiders research plans}

Sydney. The Australian government last week promised to reconsider the plans of the science minister, Chris Schacht, to reorganize public research, following protests from the scientific community and other cabinet members.

Schacht's plans include moving the Fisheries, Oceanography and Atmospheric Research divisions of the Commonwealth Scientific Industrial Research Organisation (CSIRO) into the Australian Institute of Marine Science (AIMS). By creating a giant marine research institute, he hoped to boost marine and fisheries research, and increase Australian exports.

$\mathrm{He}$ also wanted to make the Australian Nuclear Science and Technology Organisation (ANSTO) part of CSIRO. This he believed would improve ANSTO's poor public image: but this has more to do with public loathing of nuclear technology than anything else.

But the Federation of Australian Science and Technology Societies and the Public Sector Union complained that the government had not properly consulted the organizations affected; these heard of the plans only a few weeks before a government committee was to consider them. Schacht says he did not make his plans public because this would have given CSIRO more opportunity to attack them. There have been too many reviews of Australian science, he says.

Other politicians supported the scientists' cause: Senator Gareth Evans, the Minister of Foreign Affairs, opposed the CSIRO's takeover of ANSTO, while the Federal Minister for the Environment, Ros Kelly, attacked a plan to take the Division of Environmental Research out of CSIRO. The media accused Schacht of trying to make his mark in his new job.

The federal government committee has now referred Schacht's proposals to an internal and a public review. Professor Ken McKinnon, vice-chancellor of Wollongong University, will examine merging CSIRO's marine divisions with AIMS. He will also consider an alternative proposal to incorpo- rate AIMS into CSIRO. The government will start its internal review of ANSTO after it resolves the separate issue of whether to give the organization a new nuclear reactor.

Despite this setback, Schacht denies that the government has rejected his plans. He says he welcomes the exchange of views they have prompted.

Mark Lawson

\section{Malpractice denied}

Paris. The Pasteur Institute in Paris has denied any malpractice over the deaths from Creutzfeldt-Jakob disease of several children who were treated with human growth hormone between the end of 1983 and the middle of 1985 . This followed the French government's decision last week to charge the two chief doctors responsible for the production and distribution of the growth hormone with involuntary homicide over the deaths of three children who were being treated for dwarfism.

One of those charged is Jean-Claude Job, president of the organization FranceHypophyse (France Pituitary), which was responsible for collecting pituitary glands from cadavers in France and elsewhere, and distributing the hormone extracted from them. The other is Fernand Dray, head of the laboratory at the Pasteur Institute where the extraction and purification was carried out.

Last December, the Ministry of Health ordered an inquiry following reports that some of those treated with the hormone died from the nervous disease eight years later. Its report strongly criticized the institute for the conditions under which it processed the pituitary glands.

But the institute claims that the onset of the disease in 24 patients treated with the hormone - 19 have since died - was "the consequence of the risk attached to a new therapy". It says the nature of the organism causing Creutzfeldt-Jakob disease was (and is) unknown, and so it was impossible to screen the batches of hormone to discover if they were contaminated.

David Dickson 